\title{
ON THE HEART OF TEMPORARY AQUATIC MAMMALS WITH SPECIAL REFERENCE TO THE EMBRYONIC PATHWAYS
}

\author{
by
}

\author{
E. J. SLIJPER \\ Zoological Laboratory, University of Amsterdam
}

\begin{abstract}
A. INTRODUCTION
In previous research (SLijPER, 1961) it was shown that the anatomical closure of the ductus arteriosus Botalli in all Cetaceans and in the Common Seal is markedly retarded, compared with their terrestrial relatives. It was also shown that in the Common Seal the closure of the foramen ovale after birth is markedly retarded. This was not found in Cetaceans. The explanation of these phenomena required further researches, especially on the hearts of temporary aquatic Mammals, not belonging to the species Phoca vitulina. Thanks to the help of some colleagues a material of 50 hearts could be collected, belonging to 11 different species. This material made it also possible to pay attention to a few other characteristics of the heart, our knowledge of which until now was very scanty.
\end{abstract}

\section{B. MATERIAL}

The material consisted of 50 hearts, viz.: 43 hearts of different Pinnipeds, 2 hearts of Hippopotami and 5 hearts of Otters.

1. Callorhinus ursinus (L), Northern Fur Seal. The material was provided by Dr. V. B. Scheffer (Marine Mammal Laboratory, U.S. Fish and Wildlife Service, Seattle, Wash. U.S.A.). The hearts were collected on St. Paul Island, Alaska in July and August 1963. The ages of the animals were estimated by the experts who collected the material. There were 6 newborns (less than 24 hours; length 62-68 $\mathrm{cm}$; weight $4.5-5.9 \mathrm{~kg}), 2$ of 1 week $(60.5-68.5 \mathrm{~cm}$; $3.9-6.9 \mathrm{~kg}), 2$ of 2 weeks $(59.5-68.4 \mathrm{~cm} ; 4.4-8.1 \mathrm{~kg})$, 2 of 3 weeks (63.0-68.7 cm; 6.8-7.1 kg), 2 of 4 weeks $(69.4-72.2 \mathrm{~cm} ; 8.1-9.7 \mathrm{~kg}), 2$ of 5 weeks $(61.2-72.2$ $\mathrm{cm} ; 4.1-7.6 \mathrm{~kg}), 2$ of 6 weeks $(68.7-76.0 \mathrm{~cm} ; 7.1-9.0$ $\mathrm{kg}), 2$ of 7 weeks $(67.5-73.2 \mathrm{~cm} ; 7.2-7.3 \mathrm{~kg})$, and 2 of 8 weeks (76.4-112 cm; 8.7-9.4 kg).
2. Halichoerus grypus (Fabricius), Grey Seal.

One heart of a newborn $(85 \mathrm{~cm}, 14.8 \mathrm{~kg}$ ) was provided by Prof. H. R. Hewer (London), the other three (2-3 weeks, $75 \mathrm{~cm}, 10.5 \mathrm{~kg}$; 5-6 weeks, $95 \mathrm{~cm}$, $15.8 \mathrm{~kg} ; 6$ weeks) came from Texel and from the Zoological Garden "Artis", Amsterdam. The estimation of the ages was based on data about length, weight and period of birth of the species given by IJSSELING en Scheijgrond (1950, 1962), MatTHEWs (1952), KIng (1964) and Southern (1964).

\section{Pusa hispida (Schreber), Ringed Seal.}

Two hearts from specimens captured alive by Dr. Carleton Ray (New York Aquarium) on St. Lawrence Island, Alaska during the summer 1963. The material was sent by Dr. F. H. Fay (Arctic Health Research Center, Anchorage, Alaska), who estimated the ages of the animals at 5-6 weeks and 1 year.

\section{Pusa sibirica (Gmelin), Baikal Seal.}

Four hearts from specimens that died in the Zoological Garden "Artis", Amsterdam. They were bought from an animal dealer. A $64 \mathrm{~cm}, 13 \mathrm{~kg}$ female lived about 3 months in the Gardens, a $68 \mathrm{~cm}, 11.5 \mathrm{~kg}$ male, a $72 \mathrm{~cm}, 12 \mathrm{~kg}$ female and a $77 \mathrm{~cm}, 16 \mathrm{~kg}$ male lived there only 4-6 weeks. The ages of all four animals were estimated at at least 6-8 months.

\section{Odobenus rosmarus (L.), Walrus.}

Two hearts from specimens captured alive by Dr. Carleton Ray (New York Aquarium) on St. Lawrence Island, Alaska during the summer 1963. The material was sent by Dr. F. H. Fay, who estimated the ages of the animals at 4-6 days and 4 weeks. One heart from a $138 \mathrm{~cm}$ long female, weighing $59.5 \mathrm{~kg}$, bought from an animal dealer at 8-2-67. According to data given by KING (1964) the age of this animal was estimated at 6-8 weeks. 
6. Erignathus barbatus (Erxleben), Bearded Seal. One heart from a specimen captured on St. Lawrence Island, Alaska (see sub 5); age 11 days.

7. Histriophoca fasciata (Zimmerman), Banded Seal. One heart from a specimen captured on St. Lawrence Island, Alaska (see sub 5); age 5-6 weeks.

\section{Zalophus californianus (Lesson), Californian Sea} Lion.

One heart of an abortus (about one month before birth) from the Robarium, Harderwijk and one heart of a specimen, which died in the Zoological Garden "Artis", Amsterdam (at least 18 years old).

\section{Phoca vitulina L., Common Seal.}

Two hearts of 4-5-week-old animals, collected by Mr. R. C. Bishop at Prince Wm. Sound, Alaska on 2 and 4 July 1963 respectively. The ages were estimated by Dr. F. H. Fay. Two hearts from specimens washed ashore alive on the Netherlands coast; resp. 15 and $19 \mathrm{~kg}$. Their ages were estimated at 3 months. One heart from a $101 \mathrm{~cm}$ specimen $(13.3 \mathrm{~kg})$, which lived in the Zoological Gardens, "Artis", Amsterdam; age about 1 year.

10. Hippopotamus amphibius L., Hippopotamus. One of the hearts is from a $76 \mathrm{~cm}, 38 \mathrm{~kg}$, young male, which lived about 60 hours in the Zoological Garden "Blijdorp", Rotterdam, the other is of a female about 11 years old which died on 16-2-61 in the Zoological Garden “Artis”, Amsterdam.

\section{Lutra lutra (L.), Otter.}

Five hearts from resp. a juvenile male $(78.5 \mathrm{~cm}$, $3106 \mathrm{~g})$, a juvenile female $(79.3 \mathrm{~cm}, 3008 \mathrm{~g})$ with a well developed thymus, a juvenile male ( $3244 \mathrm{~g})$, an adult male $(113.5 \mathrm{~cm}, 8000 \mathrm{~g})$ and an animal about which no particulars are known. The ages of the juveniles are estimated at at least 9 months according to data given by Southern (1964).

\section{ACKNOWLEDGEMENTS}

For providing material and data about the animals, grateful acknowledgement is made to Dr. V. B. Scheffer (Seattle), Dr. F. H. Fay (Anchorage), Prof. H. R. Hewer (London), Dr. J. C. Coulson (Durham), Dr. I. A. Mc Laren (Montreal), Dr. E. F. Jacobi (Amsterdam) and Dr. A. C. V. van Bemmel (Rotterdam).

\section{DUCTUS ARTERIOSUS BOTALLI}

In a previous paper (SLIJPER, 1961) it was shown that, if the absolute size of the animals is taken into consideration, the anatomical closure of the ductus arteriosus Botalli in all Cetaceans and in the Common Seal is markedly retarded, compared with their terrestrial relatives. The anatomical closure occurs at an age of 4-14 months in the Common Porpoise and in other Delphinidae, at ages up to 13 years in Blue and Fin Whales, while closure probably also occurs at high ages in other Baleen Whales and in the Sperm Whale. In the Common Seal the ductus closes anatomically at an age of 8-13 weeks, whereas in terrestrial mammals of comparable size, as for example the dog and the pig, it closes at an age of 15-18 days and 14-21 days respectively (EvERETT and Johnson, 1951; SLIJPER and dE VriEs, 1965).

Slijper (1961) and Slijper and de VrIes (1965) showed that the time of complete anatomical closure of the ductus varies with the size of the animals. The larger the animal is, the later the time of anatomical closure. The data about the Elephant on which this statement was based, could be confirmed by the dissection of the heart of a 28 years old female Indian Elephant, which died in the Zoological Gardens "Artis" (Amsterdam) on 11-5-1967. The ductus of this animal had a diameter of $15 \mathrm{~mm}$. The major part of the vessel showed a lumen of $1.5 \mathrm{~mm}$ containing blood. Only the terminal part of the ductus embedded in the wall of the pulmonary artery showed no lumen. This ductus may be called anatomically closed, but the blood containing lumen suggests that closure had taken place not long ago. Probably an insignificant amount of blood regularly passed the ductus shortly before. In a 35-year-old female Indian Elephant (30-3-65; Artis) the ductus was completely closed. It was also completely closed in an 11 year-old Hippopotamus and a 23-year-old Black Rhinoceros. The retarded closure of the ductus in Cetaceans and Pinnipeds was explained (StrjPER, 1961) by supposing that respiratory difficulties, the exact nature of which is not yet known, may occur in Cetaceans after birth, because the animals are born in the water. They may also occur in the Common Seal because its pups are obliged to go into the water very shortly (20 min.-8 hours) after birth. The respiratory difficulties during the period immediately after birth are supposed to cause a temporary reopening of the physiologically closed ductus. This temporary re-opening and closing of the ductus may occur several times during the first weeks after birth. Consequently they may have a retarding effect on the process of anatomical closure of the ductus.

If this explanation is acceptable, it becomes quite clear that in those Pinnipeds, the young of which 
remain on land during several days or even several weeks after birth, the anatomical closure of the ductus arteriosus will not be retarded. The ductus will close at about the same age at which it closes in terrestrial mammals of comparable size.

Surjper (1961) found that in these Pinnipeds the anatomical closure of the ductus occurred at an age of 2-5 weeks. This is an even earlier age than is known of terrestrial mammals of comparable size. The conclusion was, however, based on a very scanty material. The present research enables us to broaden this basis.

Although a definite proof of the anatomical closure of the ductus can only be obtained by microscopical examination, in this research the macroscopical closure of the ductus was used as a criterion for its closure. According to SliJPER and DE Vrues (1965) the ductus can be called macroscopically closed, when in part of the vessel at least no lumen can be seen with the naked eye and when at least in part of the vessel a small probe cannot be inserted.

\section{Callorhinus ursinus, Northern Fur Seal.}

In 6 newborns the ductus was open, the outer diameter being 3-6 mm, the diameter of the lumen 1-3 $\mathrm{mm}$. In the pups of one week it was still open with a lumen of 0.5 and $0.2 \mathrm{~mm}$. In the pups of two weeks the pulmonary end of the ductus was still open, but in the $4.4 \mathrm{~kg}$ pup the aortic end was closed; in the $8.1 \mathrm{~kg}$ pup the aortic end was cut off. Both ductus had a lumen of $0.8 \mathrm{~mm}$. In all other pups the ductus was closed at both ends, the outer diameter varying between 5 and $3.5 \mathrm{~mm}$. The lumen in the middle part of the ductus had a diameter of about $0.1 \mathrm{~mm}$. These observations indicate that in the Northern Fur Seal the ductus closes at an average age of about 12 days. This is even earlier than in terrestrial animals of comparable size (pig, dog), especially if we take into account that the newborn pups of the Seal are very large (about $5 \mathrm{~kg}$; King, 1964). Data in the literature quoted by SLIJPER (1961) and data given by MAXWELL (1967) show that the pups normally do not go into the water before 3-6 weeks after birth, although they are able to swim, though in a rather helpless way. Obviously they do not dive during this period if they get into the water accidentally. According to OGNEv (1962) they would even be drowned if they get into the water during the first 4 weeks.

\section{Halichoerus grypus, Grey Seal.}

In the newborn and in the pup estimated at an age of 2-3 weeks the ductus was open. In pups whose age was estimated at 5-6 and 6 weeks it was closed.
This points to the fact that in the Grey Seal the ductus probably closes at an age of about 3 weeks. This is a little bit later than in the Northern Fur Seal. The newborn of Halichoerus, however, has twice the weight of the newborn of Callorhinuis. In any case the ductus closes at about the same age as in terrestrial animals of comparable size.

Data in the literature on this subject (see also SLIJPER, 1961) show that there is much variation in the time at which the Grey Seal pup first goes into the water. This may be connected with the variation in the age in which the embryonic coat is shed (KINc, 1964), a few pups starting the moult even before birth. About the Grey Seal of the Farne Islands Coulson and Hicksing (1964) write that the calf remains on land for an average of 32 days. In a letter of 28-4-65 Dr. Coulson (Durham), however, adds: "There is considerable variation around this figure and some of the calves born on the shore line are forced to swim within the first few hours of birth, since some of the individuals are born below high water mark. Irrespective of their age, whether they are a few hours or over a month old, they swim readily in the water without any encouragement from the mother. It is clear that the young ones are born with the ability to swim. Diving is much less frequent in young calves, but I have seen several instances of calves about 4 weeks old which have gone down to the sea for the first time, dive within seconds of entering the water." Hooke (1964) says about the Grey Seal: "they swim almost as soon as they are born". LockLey (1966) says: "Grey Seals born close to the sea learn to swim within a day or so of birth, but they do so unwillingly and only when they are forced by a high tide". There are, however, a number of pups born far inland. These animals do not go into the water before an age of about 3 weeks. All these data and those of Maxwerc (1967) point to the conclusion that, although the behaviour of the Grey Seal is very variable, at least a considerable number of the pups do not enter the water before the age of about 3 weeks.

\section{Pusa hispida, Ringed Seal.}

In a 5-6-week-old animal and in a 1-year-old specimen the ductus was completely closed. This indicates in any case that the closure of the ductus occurs at a much earlier age than in the Common Seal (8-13 weeks). The size of the adults of both animals is about the same, but the weight at birth of the Common Seal is about twice that of the Ringed Seal (KING, 1964). It is, however, not acceptable to suppose that this difference in weight at birth is respon- 
sible for the great difference in time of closure of the ductus.

According to data in the literature on the Ringed Seal the pup does not enter the water before the age of 5-6 weeks (Slijper, 1961).

\section{Pusa sibirica, Baikal Seal.}

The age of all four animals was estimated at 6-8 months. Consequently, the fact that in all four animals the ductus arteriosus was closed, gives no indication about the problem of the time of its closure. According to Maxwell (1967) the pups do not take to the water until 2-3 months after birth.

\section{Odobenus rosmarus, Walrus.}

In his letter of 22-1-63 Dr. F. H. Fay (Anchorage) writes that in 1961 he inspected hearts of one adolescent and five adult Walruses in which the ductus arteriosus was closed. It was also closed in a young animal $120 \mathrm{~cm}$ long, dissected by OwEN (1853) and in a young male $235 \mathrm{~cm}$ long, described by MURIE (1871). Dr. Fay examined a 4-6-day-old calf in which the ductus was open. In animals with an estimated age of respectively 4-6 days and 4 weeks an open ductus was found but in a young specimen with an estimated age of 6-8 weeks the pulmonary end of the vessel was closed. The middle part and the aortic end were still open. This gives an indication that in the Walrus the ductus probably closes at the age of about 8 weeks. In an animal whose size and weight may be compared with those of the cow this is a rather early age (SLrJPER, 1961). There is much controversy about the behaviour of the pup after birth (SLIJPER, 1961), even in the publications of one and the same author. Pedersen (1962) is his book "Polar Animals" says (p. 120) that "the young are born out on the ice in April, and while they are still small the whole family remains there. From time to time one of the adults takes a swim, but without going far away". This is quite in accordance with a personal communication of M. M. Sleptzov, that the young do not go into the water before they are three weeks old. On the other hand Pedersen (1962a) writes in "Das Walross", that copulation and birth never have been observed on land. He supposes that these events take place in the water. In the early stage after birth the female swims on her back with the pup between her forelegs. This is more or less in accordance with MAY's (1964) statement, that the calf is able to swim promptly after birth but that it often rides on its mothers neck; see also MaxweLI. (1967).

Although the information on the whole is not very convincing, the preliminary conclusion may be that probably the young Walrus does not swim in the early stage of its life and that at least it does not dive in that stage.

\section{Erignathus barbatus, Bearded Seal.}

In the 11-day-old male the ductus arteriosus is still open. The lumen, however, is so narrow that it makes the impression that it will close within a few days. Dr. F. H. Fay (Anchorage) writes in his letter of 22-1-63 that in 1961 he inspected 5 Bearded Seals. In one specimen that lived on land for 1I-12 days the ductus was nearly closed, in an animal of 3-4 weeks it was completely closed, as well as in 2 specimens of approximately 1 year and in an adult female. These observations lead to the conclusion that the ductus closes between the 11th and the 21st days after birth. This is about the same age at which the ductus closes in terrestrial animals of comparable size. Dr. I. A. Mc Laren (Montreal) informed us, that pups of this species remain on land at least several days after birth. Dr. F. H. Fay (Anchorage) writes in his letter of 6-2-63: "In the area about St. Lawrence Island, Bering Sea, where most of my work has been done, Bearded Seals are born mostly during the last half of April on the drifting ice. They apparently first enter the water within a few hours after birth but stay in the water only long enough to cleanse their woolly foetal coat and reach a "clean" ice floe where their hair will not become fouled again by the blood and other organic debris that was expressed with them at birth. I judge this only on the basis that newborn or very young individuals that I have seen were not on the same ice where they were born. Since their ability to control loss of body heat is very poor at that time, I also judge that they probably remain on the ice most of the time during the succeeding two or three weeks. During that time they are suckling and losing their foetal pelage".

These data point to the fact that the behaviour of the Bearded Seal with regard to diving and swimming, in the first weeks after birth, differs markedly from that of the Common Seal, at least from the behaviour of the European Common Seal. If the Bearded Seals enter the water during this time, they probably do this unfrequently and without diving.

\section{Histriophoca fasciata, Banded Seal.}

In a 5-6-week-old pup the ductus was still open. This indicates that the closure of the ductus occurs at a later age than in terrestrial Mammals of comparable size (adult about $90 \mathrm{~kg}$; KING, 1964). 
Dr. F. H. Fay (letter of 6-2-63) informs us, that in the area about St. Lawrence Island (Alaska) Banded Seals stay out of water most of the time until they have lost their foetal coat, just as Ringed Seals and Common Seals. By that time they are weaned and all very fat and apparently able to withstand the cooling effect of the icewater.

Unfortunately our material does not indicate whether the closure of the ductus is as much retarded as in the Common Seal, or whether the animal shows an intermediate position between the Common Seal and the terrestrial Mammals with regard to this characteristic.

8. Zalophus californianus, Californian Sea Lion. As might be expected, the ductus was closed in an 18-year-old animal.

\section{Phoca vitulina L., Common Seal.}

In two animals of 4-5 weeks the ductus was cut off. In the animals with an age of 3 months, 3 months and 1 year respectively, the ductus was closed on both sides. There was an insignificant lumen in the middle. These data are in accordance with former observations (SrIJPER, 1961), leading to the conclusion that in the Common Seal the ductus closes anatomically at the age of 8-13 weeks.

Former data about the behaviour of the newborn (it swims and dives perfectly even about 20 minutes after birth (KLINKHART, 1967) and remains in the water for long periods) were confirmed by observations in the Amsterdam Zoological Gardens "Artis" and by references from the literature on the subject, as for example with MAY (1964) and MANSFIELD (1963) (Arctic and Eastern Canadian animals). About the Common Seals of the Bering Sea Dr. F. H. Fay (letter of 6-2-63) reports, that they are born with their foetal pelage. This may be the reason why they stay out of water most of the time until they have lost their foetal coat. The animal described by KLINKHART (1967), however, was born on Tugidah Island, Alaska. Our conclusions about the retarded closure of the ductus arteriosus in Cetacea and in the Common Seal were, however, based on the European Common Seal living in temperate regions, in any case not in Arctic regions. The pups of these Seals are mostly born on the sand banks when these are dry at low tide. At high tide the banks are overflown by the sea water and the newborns are forced to swim and dive within 1-8 hours after birth. According to Havinga (1933) the intra-uterine moulting may be regarded as an adaptation to this habit.
10. Hippopotamus amphibius, Hippopotamus. In the 60-hour-old animal the ductus was anatomically open, in the 11-year-old female it was closed. These observations do not lead to conclusions about the time of closure.

\section{Lutra lutra, Otter.}

Because the animals involved were at least 9 months old, no conclusions could be drawn from this material. In one adult animal the ligamentum Botalli was present as a very thin ligament. In the other four hearts not a single trace of the ligament was found. Apparently it may disappear completely. MARSCHNER (1901) describes, however, a solid ligament in an adult specimen, $68 \mathrm{~cm}$ long.

The above-mentioned data show that the information about the ductus arteriosus and about the behaviour of the newborn animals in the Northern Fur Seal, the Grey Seal, the Ringed Seal, the Walrus, the Bearded Seal and the Banded Seal confirms SLIJPER's (1961) preliminary conclusion.

In these Pinnipeds the ductus arteriosus closes anatomically at the same time or even earlier than in terrestrial Mammals of comparable size. Their newborns remain on land for several weeks or, if they swim during the first weeks, they do so very unfrequently, and they do not dive. This behaviour differs markedly from that of the Common Seal in which the closure of the ductus is retarded because the young animals are forced to swim and to dive almost immediately after birth.

The ductus arteriosus of the Pinnipeds is characterized by its length. In the hearts involved in this research the length varied between 9 and $20 \mathrm{~mm}$, in the Walrus even between 9 and $25 \mathrm{~mm}$. It rises from the aorta and the pulmonary artery in a more or less pronounced depression of the aortic or pulmonary wall. The anatomical closure may start at the aortic (Northern Fur Seal, Common Seal) as well as at the pulmonary end (Baikal Seal). In the middle of the vessel an insignificant lumen may be present for a comparatively long time.

The microscopic structure of the ductus was examined in the Northern Fur Seal, the Bearded Seal, the Grey Seal, the Common Seal and the Walrus. The intima is thickened in all species with the exception of Callorhinus. There is a well developed elastica interna which apparently remains intact fairly long during the process of closure of the ductus, just as in the pig (SLIJPER en DE VRIES, 1965), but contrary to the rat, where there is no elastica interna at all (HoEfsmrt, 1967). 
The media contains a gradually diminishing amount of muscle fibres and comparatively few elastic fibres, with the exception of Callorhinus where a large amount of elastic tissue was found in the media. In all species the adventitia is characterized by a great number of concentric elastic membranes. The structure of the wall of the ductus shows no essential differences with its structure in terrestrial Mammals, nor with its structure in Cetacea (SLIJPER, 1961). Neither are there essential differences between the Common Seal and the other Pinnipeds. No signs of aortification of the ductus, like those described in the ductus arteriosus persistens (HoEfSMrT, 1967), have been found in Cetacea and in the Common Seal.

Vasa vasorum were found as small arteries and veins in the adventitia and as capillaries in the outer half of the media in all species examined. This is quite in accordance with the situation in Cetacea, in the Common Seal, in the Pig and the Guinea Pig (SLIJPER and DE Vrues, 1965). In man the vasa vasorum penetrate into the outer half of the media in the first week after birth. In the second week they penetrate also into the intima and at the end of the third week the entire wall of the ductus is vascularized (Clarke, 1965). In the cow the entire media and adventitia are vascularized (HaRMs, 1966).

In the carotid arteries, the aorta, the pulmonary artery and the coronary arteries of man and some other Mammals, vasa vasorum mostly penetrate into the media to about $2 / 3$ of its transverse diameter (Clarke, 1964, 1965a; van Limborg, 1959; Suwa c.s., 1962; WoERnER, 1959).

All results of the present research confirm SLIJPER's (1961) conclusion that the microscopic structure of the ductus arteriosus, as well as the histological process of its closure, are quite the same in aquatic and terrestrial Mammals irrespective of the time after birth at which the ductus closes anatomically.

\section{E. FORAMEN OVALE}

In all Pinnipeds dissected the situation of the foramen ovale and its valve protruding into the left atrium was practically the same as in man and the domestic animals. About the time of closure of the foramen the following observations were made:

\section{Callorhinus ursinus, Northern Fur Seal.}

The foramen was open in 6 newborns, in 11 animals of 1-6 weeks and in one animal of $76.4 \mathrm{~cm}, 8.7 \mathrm{~kg}$, whose age was estimated at 8 weeks. In the newborns the diameter of the opening was about $6 \mathrm{~mm}$, in the other animals it varied from $2-7 \mathrm{~mm}$. The foramen was completely closed in one animal of 4 weeks, two animals of 7 weeks and one animal of 8 weeks. These data are in accordance with those found by SLIJPER (1961). They point to the fact that in the Northern Fur Seal the foramen closes at the age of 7-9 weeks, although occasionally it may close at an earlier time. The width of the opening at birth is maintained until the time of closure. In all animals with a closed foramen the ductus arteriosus was also closed. Eight animals with an open foramen, however, had a closed ductus.

\section{Halichoerus grypus, Grey Seal.}

In a newborn and in a 5-6-week-old animal the foramen was open, although the diameter was only $2 \mathrm{~mm}$ in the 5-6-week-old animal. In animals of resp. 2-3 and 6 weeks the foramen was closed. Probably the average time of closure is about 6 weeks. The 2-3-week-old animal had an open ductus, in the 5-6-week-old animal the ductus was closed.

\section{Pusa hispida, Ringed Seal.}

The foramen of a 5-6-week-old animal made the impression that it had just closed. The one-year-old animal had a completely closed foramen.

\section{Pusa sibirica, Baikal Seal.}

In all 6-8-month-old animals the foramen was closed.

\section{Odobenus rosmarus, Walrus.}

In the 4-6-day-old and 4-week-old animals the foramen was open with a diameter of 18 and $7 \mathrm{~mm}$. In a 6-8-week-old animal it was closed. The same situation was found with regard to the ductus arteriosus. In his letter of 22-1-63 F. H. Fay (Anchorage) writes that he found an open foramen in a calf of 4-6 days, whereas it was closed in 1 adolescent and 5 adults. In the $120 \mathrm{~cm}$ long animal dissected by Owen (1853), whose age was probably about 6 weeks, the foramen and the ductus were closed. These observations point to a closure time of the foramen of about 5 weeks.

\section{Erignathus barbatus, Bearded Seal.}

In the 11-day-old animal the open foramen showed a diameter of $13 \mathrm{~mm}$. F. H. Fay found an open foramen in an 11-12-day-old animal, but it was closed in a specimen of 3-4 weeks, in two one-year-old animals and in an adult female. Probably the foramen closes at the age of about 3 weeks. 
7. Histriophoca fasciata, Banded Seal.

In the 5-6-week-old animal, which had an open ductus arteriosus, the foramen ovale was closed.

\section{Phoca vitulina, Common Seal.}

Dissections of 20 Common Seals (SLIJPER, 1961) have shown that in this species the foramen ovale closes at the age of 8-13 weeks. This is in accordance with the present observations on an animal of one year (closed) and two animals of approximately 3 months (one open, one closed). In two 4-5-week-old specimens the foramen was closed. These animals, however, were caught in Alaska, whereas the other specimens were of European origin. Probably the behaviour of the Alaskan young animals with regard to swimming, diving or other circumstances differs from that of their European relatives. Unfortunately no data about their ductus arteriosus could be obtained.

About the time of closure of the foramen ovale in terrestrial mammals very little exact information is available, especially because the foramen closes gradually. Patten (1931) showed that in man the closure of the foramen is not completed until about 7 months after birth. Approximately $25 \%$ of all adult hearts show incomplete adhesion with "probe patency". In other mammals also a certain percentage of adult animals still have one or two small openings in the foramen. In some species (as for example the Pig) even sometimes a large opening (SLXJPER, 1961) may be found. From data in the literature quoted by SLIJPER (1961) and from data given by ElLENBERGerBAUM (1943), BorN c.s. (1954), Dawes (1964), and Condorelli and UnGaru (1960) the preliminary conclusion may, however, be drawn that, apart from one or two very small openings which may occur occasionally, the foramen closes in Man and in the Sheep at the age of about 8 days, in the Dog at the age of about 3 weeks, in the Pig at the age of 7-10 days (Slijper and de Vries, 1965), in horses and cows at the age of 3-5 weeks (according to Dawes (1964) in the horse at the age of 2 days) and in the Rabbit at the age of about 12 days. In an 8-day-old Bactrian Camel it was still wide open, but in a young Hippopotamus which was at most of the age of 60 hours, it was completely closed. In all Otters examined it was also closed. According to Patten (1931) the orifice of the human foramen ovale at birth is about 30.1 square $\mathrm{mm}$. In the 7 th week it is already reduced to $9.1 \mathrm{~mm}$.

Taking into account that if in the present paper a foramen ovale is called open, it is wide open (approximately the same opening as at birth), the con- clusion may be drawn, that compared with their terrestrial relatives, all Pinnipeds show a more or less retarded closure of the foramen ovale. This conclusion is different from the conclusion drawn in my paper of 1961. The retardation is most evident in the Common Seal, but it is also very obvious in the Northern Fur Seal. This means that the difference in swimming behaviour between the two species, which provided an explanation for the retarded closure of the ductus arteriosus, cannot be responsible for the retardation of the closure of the foramen ovale.

Probably there is no direct relation between the two processes. This is confirmed by the fact that in many (but not in all) cases an open ductus and a closed foramen or an open foramen and a closed ductus were found in the same heart. In the other Pinniped species the closure of the foramen was not as much retarded as in the Common Seal and the Northern Fur Seal. Taking into account our scanty knowledge about what happens exactly in terrestrial mammals, we may, however, conclude that also in these Pinnipeds the process is retarded. An acceptable explanation of the phenomenon cannot yet be given.

\section{F. RAMIFICATION OF THE AORTIC ARCH}

In the material involved three different types of ramification of the aortic arch can be distinguished.

The most common type corresponds with the situation found in Man, where there are three branches of the aortic arch, viz.: an art. anonyma (branching into the art. subclavia dextra and the art. carotis communis dextra), an art. car. comm. sin. and an art. subclavia sin. This type was found in 4 out of 14 hearts of Callorhinus ursinus and in all hearts of Halichoerus grypus, Pusa hispida, Pusa sibirica, Erignathus barbatus, Histriophoca fasciata and Phoca vitulina. It has been described by MeckeL (1831), Bürow (1838), MARSCHNER (1901) and MÜLLER (1941) in Phoca vitulina and by Murue (1874) in Eumetopias jubatus. The same type is found in most Mysticetes and in Sirenians (Sluyper, 1936; type A2 and A2a).

A more concentrated type of ramification, corresponding with the situation found in the Dog and the Pig, consists of an art. brachiocephalica (branching into the art. subclavia d., the art. car. comm. d. and the art. car. comm. sin.) and an art. subclavia sin. It was found in 10 out of 14 hearts of Callorhinus ursinus (see also MülLER, 1941).

It was also found in the Hippopotamus and in the Otter. It has not been found in Cetacea. A more 
dispersed type of ramification in which all four arteries arise separately from the aortic arch, was found in Odobenus rosmarus. In this animal it was already described by OwEN (1853) and MurIe (1871).

It has been shown (SLIJPER, 1936) that the type of ramification of the aortic arch is determined by the spatial relations in the cranial part of the thoracic cavity. A concentrated type is found in animals with a narrow cranial part of the thorax, a dispersed type is found in animals where this part is wide. The type is also determined by the way in which the heart is situated in the thorax. In this research, however, these relations could not be examined, because the hearts could not be examined in situ.

\section{G. DILATATION OF THE AORTIC ARCH}

With regard to the Walrus MurIE (1871) writes: "The aortic arch has a capacious thick-walled dilatation opposite the obliterated ductus arteriosus". This very remarkable dilatation was also found in the three specimens of the present material. They showed a similar dilatation in the pulmonary artery. MARSCHNER (1901) pointed to the fact that this is not an aneurisma, because the walls of the vessels are thickened instead of thinned. According to several authors quoted by MARSCHNER (1901) the dilatation also occurs in the aorta of the Common Seal. Bünow (1838), however, says that in this species an inconspicuous dilatation of the aortic arch is only found in young animals. In the present material no dilatation was found in the aortic arch and the pulmonary artery of Callorhinus ursinus and Phoca vitulina (see also MüLLER, 1941). Two specimens of Halichoerus grypus also had no dilatations. In two other specimens of this species an insignificant dilatation was found in the aortic arch as well as in the arch of Pusa sibirica. Histriophoca fasciata shows a moderate dilatation of the aorta, whereas there is a fairly large dilatation of the arch in Erignathus barbatus.

Murre (1874) described the phenomenon in Eumetopias jubatus. No dilatation was found in the Otter and the Hippopotamus. The above mentioned facts show that in the Pinnipedia the same phenomenon is met with as in Cetacea (SLrJPER, 1962): some species show remarkable dilatations of the aortic arch and even of the pulmonary artery, whereas in others no trace of such a dilatation can be found. The functional significance of the dilatations remains obscure.

\section{H. THE SHAPE OF THE HEART}

KING's (1964) statement that the Otariid heart is longer, firmer and more compact than the flatter, more quadrangular and flabby Phocid heart, could not completely be confirmed. The hearts of the foetal and the 18-year-old Californian Sea Lion both showed a length to breadth ratio of $87: 100$. The hearts of the newborns of the Otariid Callorhinus ursinus were as broad as they were long (ratio 100\%), but in animals of 8 weeks and older the length: breadth ratio was about $120 \%$. This confirms also the description of Müller (1941). In all other Pinniped species the length: breadth ratio varied between 61 and 96\%. They all belong to the Phocids with the exception of the Walrus. In the Otter the index varied between 112 and 136, in the Hippopotamus it was 90.

It is quite evident that the shape of the heart is principally determined by the spatial relations in the thoracic cavity as, for example, has been pointed out by Dwigrt Davis (1964) with regard to Bears and by SLIJPER (1962) with regard to Cetaceans. These relations, however, could not be studied at the present material.

\section{THE THICKNESS OF THE VENTRICULAR WALLS}

In the ordinary textbooks of human and veterinary anatomy it is stated that the left ventricular wall of the heart is about three times as thick as the right. According to LATIMER (1953) in 153 adult human hearts the ratio of the thickness of the left ventricular wall: right ventricular wall was 2.66. The ratio of the weight of these walls appeared to be 2.27 in man (Latimer, 1953), 1.96 in Guinea pigs (Latimer, 1952) and 1.80-1.87 in adult dogs (LATIMER, 1961). The phenomenon is explained by the difference in pressure in the aortic and the pulmonary system.

Because of the open embryonic pathways before birth the pressure in the right ventricle of the foetus is almost the same as in the left ventricle. Consequently the thickness and the weight of both ventricular walls may be expected to be the same in newborns. This is what MüLler (1883) found in man and LATIMER (1965) in newborn dogs. KYrIELEIS (1963) has shown that there is even an absolute decrease in thickness of the right ventricular wall, (1.63 $\mathrm{mm}$ ) during the first months of human postnatal life. In the hearts of all newborn Pinnipeds as well as in a heart of a newborn Hippopotamus and a newborn Bactrian Camel the thickness of the left and right ventricular wall appeared to be the same. But already in one-week-old animals of Callorhinus, Odobenus and Erignathus the ratio of the thickness of the ventricular walls was resp. 44-58, 88 and 66 (right wall in $\%$ of left wall). In 2-3-week-old animals (Callorhinus and Halichoerus) the ratio was 50-55, 
38 and 35 , whereas in all older animals it varied between 50 and 25 with an average of about 35 . The same ratio was found in the adult Otters. These data show that in newborn as well as in adult Pinnipeds the same ratio of the thickness of the two ventricular walls is found as in terrestrial Mammals. The time in which the adult ratio is reached is definitely not longer, probably even shorter, than in terrestrial Mammals (Müller, 1883; Kyrieleis, 1963). Neither the retarded closure of the foramen ovale, nor the characteristics of the circulatory system connected with diving, have affected the thickness of the ventricular walls.

\section{J. SUMMARY}

1. Researches were made on $\mathbf{5 0}$ hearts of $\mathbf{9}$ different Pinnipeds, of the Hippopotamus and the Otter.

2. In the Northern Fur Seal, the Grey Seal, the Ringed Seal, the Bearded Seal, the Banded Seal and the Walrus the ductus arteriosus closes anatomically at the same time, or even earlier, than in terrestrial Mammals of comparable size. In contrast to those of the Common Seal the newborn pups of these animals remain on land for several weeks, or, if they swim during the first weeks after birth, they do so infrequently and they do not dive.
These data confirm the supposition that the retarded anatomical closure of the ductus arteriosus in Cetaceans and in the Common Seal may be explained by the fact that their newborns swim and dive immediately or almost immediately after birth. Shortage of oxygen (or eventually a rise of the pressure in the pulmonary artery) may cause a temporary re-opening of the ductus during the first period of postnatal life, which retards its anatomical closure.

3. All Pinnipeds show a more or less retarded closure of the foramen ovale during the first period of postnatal life. Obviously this phenomenon is not directly related with the closure of the ductus arteriosus.

4. In most Pinnipeds a ramification of the aortic arch was found, which corresponds with the situation in Man. Some animals show a more concentrated type, like the Dog and the Pig. The Walrus has a more dispersed type.

5. Data are given about the shape of the heart. This shape and the type of ramification of the aortic arch are highly correlated with the spatial relations in the thoracic cavity.

6. The ratio of the thickness of the right and left ventricular wall in Pinnipeds is the same as in terrestrial Mammals. This is the case in newborns as well as in young and adult animals.

\section{REFERENCES}

Born, G. V. R., G. S. Dawes, J. C. MotT and J. G. WIDDICOMBE, 1954: Changes in the heart and lungs at birth. In: Cold Spring Harbor Symposia 19. The Mammalian Fetus, Biol. Lab. Cold Spring Harbor, New York, p. 102.

Bürow, 1838: Über das Gefäss system der Robben. Archiv Anat. Phys. p. 230.

Clarke, J. A., 1964: An X-Ray microscopic study of the vasa vasorum of normal human coronary arteries. Journ. Anat. 98 , p. 539.

- 1965: An X-Ray microscopic study of the vasa vasorum of the human ductus arteriosus. Journ. Anat. 99, p. 527.

- 1965a: An X-Ray microscopic study of the vasa vasorum of the normal human pulmonary trunk. Acta Anat. 61, p. 6.

Condorelli, S. and C. UNGARI, 1960: The period of the functional closure of the foramen ovale and the ductus Botalli in the human newborn. Cardiologia 36, p. 274.

Coulson, J. C. and G. Hickling, 1964: The breeding biology of the Grey Seal on the Farne Islands. Journ. Anim. Ecology 33, p. 485.

DAwes, G. S., 1964: Physiological changes in the circulation after birth. In: A. P. Fishman and D. W. Richards,
Circulation of the Blood. Oxford Univ. Press, p. 743. Dwight Davis, D., 1964: Anatomy of the heart in Bears (Ursidae). Gegenb. Morph. Jahrb. 106, p. 553.

ELLENBERGER-BAUM, 1943: Handbuch der vergleichenden Anatomie der Haustiere, 18. Aufl. Berlin, Springer.

EveretT, N. B. and R. J. Johnson, 1951: A physiological and anatomical study of the closure of the ductus arteriosus in the dog. Anat. Record 110, p. 103.

HARMS, D., 1966: Uber den Bau und Verschluss des Ductus arteriosus Botalli des Rindes. Zeitschr. f. Zellforschung 72 , p. 344 .

HavingA, B., 1933: Der Seehund in den holländischen Gewässern. Tijdschr. Ned. Dierk. Vereen. (3) 3, p. 79.

HoEfsMir, E. C. M., 1967: Het sluitingsproces van de ductus arteriosus bij de rat. Diss. Leiden.

Hooke, W. N., 1964: The Seal Summer. A. Barker Ltd, London.

King, J. E., 1964: Seals of the World. British Museum (Natural History), London.

KinkHarT, E. C., 1967: Birth of a Harbor Seal pup. Journ. Mammal. 48, p. 677.

KYRIELEIS, C., 1963: Die Formveränderungen des menschlichen Herzens nach der Geburt. Virchows Arch. Path. Anat. 337, p. 142. 
LATIMER, H. B., 1952: Weights of the right and left ventricular walls in the guinea pig heart. Anat. Rec. 113, p. 247.

- 1953: The weight and thickness of the ventricular walls in the human heart. Anat. Record 117, p. 713.

- 1961: Weights of the ventricular walls of the heart in the adult dog. Univ. Kansas Science Bulletin 42, p. 3.

- 1965: The weight and thickness of the two ventricular walls in the newborn dog heart. Anat. Record 152, p. 225.

LIMBORG, J. VAN, 1959: Vasa vasorum. Ned. Tijdschr. Geneesk. 103, p. 1725.

LockLEY, R. H., 1966: Grey Seal, Common Seal, A. Deutsch Ltd London.

Mansfield, A. W., 1963: Seals of Arctic and Eastern Canada. Fisheries Research Board of Canada Bulletin 137.

Marschner, L., 1901: Beiträge zur Anatomie und Physiologie des Herzens und der grossen Gefässstämme der Wassersäugetiere. Inaug. Diss. Breslau.

Matthews, L. Harrison, 1952: British Mammals. Collins, London.

Maxwell, G., 1967: Seals of the World. Constable, London.

May, Ch. P., 1964: A second book of Canadian Animals. Macmillan Co, Toronto.

MeCKel, J. F., 1831: System der vergleichenden Anatomie. Renger, Halle.

Müller, E., 1941: Zur Anatomie des Robbenherzens. Morphol. Jahrb. 85, p. 59.

MülleR, W., 1883: Die Massenverhältnisse des menschlichen Herzens. Hamburg und Leipzig.

MurIE, J., 1871: Researches upon the anatomy of the Pinnipedia, part I, On the Walrus. Trans. Zool. Soc. London 7, p. 411.

- 1874: Researches upon the anatomy of the Pinnipedia
III. Descriptive anatomy of the Sea Lion. Trans. Zool. Soc. London 8, p. 501 .

OGNEV, S. I., 1962: Mammals of U.S.S.R. and adjacent countries Vol 3, Carnivora. Transl. from Russian by Israel Program Scient. Translations. Jerusalem.

OWen, R., 1853: On the Anatomy of the Walrus. Proc. Zool. Soc. London, p. 103.

PatTen, B. M., 1931: The closure of the foramen ovale. Americ. Journ. Anat. 48, p. 19.

Pedersen, A., 1962: Polar animals, G. G. Harrap and Co, London.

- 1962a: Das Walross. Neue Brehm Bücherei 306, Wittenberg.

SciaccA, A. and M. Condorell, 1960: The Involution of the Ductus arteriosus. Bibliotheca Cardiologica 10, Karger, Basel.

SLIJPER, E. J., 1936: Die Cetaceen, vergleichend-anatomisch und systematisch. Diss. Utrecht 1936, Capita Zoologica 6 and 7.

- 1961: Foramen ovale and ductus arteriosus Botalli in aquatic mammals. Mammalia 25, p. 529.

- 1962: Whales. Hutchinson, London.

SLIJPER, E. J. and R. J. DE VRIES, 1965: The closure of the foramen ovale and the ductus arteriosus Botalli in the domestic pig. Mammalia 29, p. 602 .

SoutheRN, H. N., 1964: The handbook of British Mammals. Blackwell, Oxford.

SuwA, K., c.s., 1962: A study on the supply of vasa vasorum to the tunica media of the common carotid arteries in rabbits. Acta Med. Okayama, 16/6 Suppl. p. 81.

WOERNER, C. A., 1959: Vasa vasorum of arteries. In: LANSING, A. J., 1959: The arterial Wall. Williams and Wilkins, Baltimore.

IJsseling, M. A. and A. Scheijgrond, 1950: De zoogdieren van Nederland. 2e dr. Thieme, Zutphen.

- 1962: Onze Zoogdieren. Thieme, Zutphen. 